\title{
The TRANSFOR success story: International forestry education through exchange
}

\author{
by John R. Spence ${ }^{1}$, David A. MacLean ${ }^{2}$, Heinrich Spiecker ${ }^{3}$, Alex Drummond ${ }^{1}$, Dirk Jaeger², Marianne Stadler ${ }^{3}$, \\ Christine Cahalan ${ }^{4}$, Anders Karlsson ${ }^{5}$, Andy Kenny ${ }^{6}$, Bruce Larson7, Blas Mola-Yudego ${ }^{8}$, Maria Sterner ${ }^{5}$, \\ Diane Wästerlund ${ }^{5}$ and Erik Valinger ${ }^{5}$
}

\begin{abstract}
The TRANSFOR (Transatlantic Education for Global Sustainable Forest Sector Development) program has promoted international student and staff exchanges among four Canadian (Alberta, British Columbia, New Brunswick and Toronto) universities and universities in four European countries (Germany [Freiburg], Finland [Joensuu], Sweden [Swedish University of Agricultural Sciences, Umeå] and the United Kingdom [Bangor University, Wales]). The program incorporated five components: one or two semester study visits for undergraduate forestry students, working internships, summer field courses, study visits for academic staff, and TRANSFOR project meetings. The summer field courses were a highly innovative part of the program and allowed students to spend three to four weeks learning about forestry activities and challenges on a continent different from that of their home institution. The program fostered internationally focused understanding of forest ecology and management, as well as economic and cultural factors, as will be required to develop effective international standards for sustainable forest management. Most student participants reported that it was a very positive experience and a high point of their education.
\end{abstract}

Key words: international exchange, undergraduate forestry students, internships, field courses, international forestry

\begin{abstract}
RÉSUMÉ
Le programme TRANSFOR (Transatlantic Education for Global Sustainable Forest Sector Development (Formation transatlantique sur le développement mondial de la foresterie durable)) a mis en place des échanges internationaux détudiants et de personnel enseignant entre quatre universités canadiennes (Alberta, Colombie-Britannique, NouveauBrunswick et Toronto) et des universités de quatre pays européens (Allemagne [Freiburg], Finlande [Joensuu], Suède [Université suédoise des Sciences agricoles, Umeå] et Royaume-Uni [Université Bangor, Pays de Galles]). Le programme comprend cinq éléments : un ou deux semestres de visites détudes pour les étudiants au baccalauréat, des stages de travail, des cours pratiques dété, des visites détudes pour le personnel enseignant et les réunions du projet TRANSFOR. Les cours pratiques dété ont constitué un élément très innovateur du programme et ont permis aux étudiants de passer de trois à quatre semaines à se familiariser avec les activités forestières et les défis sur un continent différent de celui de leur maison d’enseignement. Le programme a cherché à se concentrer sur une compréhension internationale de lécologie et de l’aménagement des forêts, ainsi que des facteurs économiques et culturels, telle qu’il sera nécessaire pour développer des normes internationales effectives d'aménagement forestier durable. La plupart des étudiants participant au programme ont souligné qu'il s'agissait d'une expérience très positive et d’un point culminant de leur formation.
\end{abstract}

Mots clés : échange international, étudiants au baccalauréat en foresterie, stage, cours pratiques, foresterie internationale

\section{Introduction}

Forests are a global resource and, in powerful ways that we increasingly recognize, are relevant to overall human welfare through their impact on global processes such as the carbon and hydrological cycles, in addition to the obvious economic and life-style considerations. Thus, effective management of forests everywhere on the planet is of some consequence to everyone, and foresters across the world continue to manage an incredible range of tree species and forest types to meet varying locally defined objectives, ranging from conservation to high intensity fibre extraction from plantations. These managed forests occur in many climactic zones, on a wide range of landscapes and soil types, and on lands ranging in ownership from small privately-owned woodlots to large tracts of publiclyowned land. Nonetheless, there are few effective international standards for forest management, although these are beginning to arise through consumer-driven pressures for certification and carbon management. Development of workable international standards and guidelines for practice will require broad understanding both of forest ecology and socioeconomic context-understanding of the sort that few forestry professionals achieve long before the end of their careers.

\footnotetext{
${ }^{1}$ Department of Renewable Resources, University of Alberta, Edmonton, Alberta T6G 2H.

${ }^{2}$ Faculty of Forestry and Environmental Management, University of New Brunswick, Fredericton, New Brunswick E3B 6C2.

${ }^{3}$ Institute for Forest Growth, Albert-Ludwigs-Universität Freiburg, Tennenbacherstraße 4, 79085 Freiburg i. Br., Germany.

${ }^{4}$ School of the Environment and Natural Resources, Bangor University, Gwynedd LL57 2UW, United Kingdom.

${ }^{5}$ Faculty of Forest Sciences, Swedish University of Agricultural Sciences, SE-901 83 Umeå, Sweden.

${ }^{6}$ Faculty of Forestry, University of Toronto, 33 Willcocks Street, Toronto, Ontario M5S 3B3.

${ }^{7}$ Faculty of Forestry, University of British Columbia, 2424 Main Mall, Vancouver, British Columbia V6T $1 Z 4$.

${ }^{8}$ Faculty of Forest Sciences, University of Joensuu, PO Box 111, FI-80101 Joensuu, Finland.
} 
In many countries, forest management writ large is a central economic activity, whether it relates to providing a sustainable base for forest products, using trees as important aspects of agriculture in agroforestry, ensuring an adequate and high-quality water supply, supporting a tourism industry or underpinning other socially and economically important functions. As mentioned above, the forest sector is increasingly global in context but necessarily incorporates local and national variations. Unfortunately, students, even in the most progressive forestry education programs, receive insufficient exposure to the range of factors that drive the global forest sector and thus rarely understand the variation in forest management that it comprises. The TRANSFOR program attempted to address this by providing students with a broad view of forestry challenges in North America and Western Europe.

"TRANSFOR" (Transatlantic Education for Global Sustainable Forest Sector Development) is a trans-Atlantic venture that has promoted exchanges of staff and students between four European and four Canadian forestry schools. Consortia like TRANSFOR allow schools to participate effectively in exchanges by balancing student participation over multiple institutions. In other words, there need not be a 1:1 exchange match between pairs of institutions in order to keep the programs revenue neutral in the long run for all participants, given that students pay their tuition at home. TRANSFOR has been sponsored by the European Union (EU) and Human Resources and Skills Development Canada (HRSDC) and Natural Resources Canada's Canadian Model Forest Program (CMFP), under the International Academic Mobility program. The project supported three-week summer field courses in Europe and Canada for students interested in forest management, in addition to more standard exchanges of students and academic staff members for study or work as guests in the forestry program of an institution on the other continent. In this paper, we describe the origin, structure, advantages and prospects of the TRANSFOR program as a model for effective exchanges.

\section{Origin and Structure of TRANSFOR Programs}

TRANSFOR was initiated in October 2004, principally through the efforts of Dave MacLean at the University of New Brunswick in Canada and Heinrich Spiecker at the University of Freiburg in Germany. They and a group of enthusiastic collaborators forged a consortium of forestry schools at universities in Canada and Europe. TRANSFOR has involved the
Universities of Alberta (UA), British Columbia (UBC), New Brunswick (UNB) and Toronto (UT) in Canada and the Universities of Freiburg (Germany), Joensuu (Finland), Bangor (UK) and Swedish University of Agricultural Sciences, Umeå (Sweden) from the EU. The supporting grants received from the EU and HRDSC were derived from a proposal promising to 1) support the development of foresters and forest scientists with a stronger international perspective, and 2) to assist the partner institutions with efforts to make their programs more appealing to motivated students in the early phases of career development who could be drawn into careers in forest science and forest management. Feedback from students clearly demonstrates that TRANSFOR successfully met these goals in its four years of operation.

The program included five main components to promote international understanding and education in the area of forestry:

1. one or two semester study visits abroad for students,

2. working internships,

3. summer field courses for students,

4. short or long-term study visits abroad for academic staff,

5. TRANSFOR project meetings.

Participation in these opportunities is summarized in Table 1. In total, 133 student exchanges with scholarships and nine without scholarships were organized during the fouryear program. Overall, student exchange was well balanced between Canadian and European participants, although participation in official "internship" opportunities sponsored under TRANSFOR involved only European students working in Canada. Participation of Canadian students in TRANSFOR internships was slower to develop than for European students. It is possible the numbers of Canadians participating in internships might catch up, as happened in other aspects of the program, if the TRANSFOR exchange opportunities were continued. However, given the excellent opportunities for paid short-term work in the Canadian forest sector, unpaid internships may be less attractive for Canadian students. Below is a brief summary of each exchange component of TRANSFOR.

\section{Student Study Visits}

Not only do students who experience a new university, country, and culture as a function of "exchange" profit from a program like TRANSFOR, but the exchange is also broadly advantageous to students at partner institutions. Foreign students contribute significantly to development of a more

Table 1. Numbers of students/staff participating in the various exchange aspects of the TRANSF0R program 2005-2008 and support provided through the TRANSFOR grants.

\begin{tabular}{lccl}
\hline Exchange & Europe to Canada & Canada to Europe & TRANSFOR funding \\
\hline Student visits & 24 & 22 & Air fares and living allowance \\
Internships & 7 & 0 & Air fares and living allowance \\
Field courses & $50^{\mathrm{a}}$ & 39 & Air fares and contribution toward in continent costs \\
Staff visits & $7^{\mathrm{b}}$ & 5 & Air fares and living allowance \\
Project meetings & 9 & 8 & Travel expenses \\
\hline
\end{tabular}

ancludes nine students without scholarships.

bIncludes four TRANSFOR-organized visits paid by other means 
international perspective among both students and staff at host institutions. Furthermore, students returning from exchange enrich the programs of students at their home institution by injecting their experiences into classroom interactions, seminars and informal discussion. Influences of both foreign exchange and returning students dramatically increased the interest of local students in participating in exchanges and were important in stimulating additional Canadian students to consider the possibility of exchanges. Taken together, these aspects have resulted in an improved vision of career opportunities and desired personal career contributions among students. In addition to the forestry-specific enrichments, students who participate in exchange programs like TRANSFOR reap the benefits of language and cultural enrichments that broaden their personal perspectives and, no doubt, contribute to improved international understanding and relationships. TRANSFOR exchanges have built what seem to be lasting bonds among Canadian and European students and imagine that such bonds have much potential to make the world a better place in perhaps small but significant ways.

Effective organization of these exchanges required attention to assist students in ensuring minimal impact on their degree programs. In some cases, participation in exchange came with the requirement for an additional academic term for students to complete their degrees, and without competent interactive advising at both partnering institutions, this requirement can significantly deter students from following through on an initial interest in exchange. Students who have been required to spend an extra term of study in order to participate in an exchange have generally found that benefits of the experience easily justified the extra work; however, this reality is best accommodated as informed decision, rather than as disappointing surprise. With sufficient lead time to make full use of "elective" courses and generate curricular flexibility at the home institution, students were able to build effective one- or two-term exchanges into a normal program. This required that each institution have at least one experienced advisor, who was intimately familiar with the exchange program and willing to work with students to develop effective schedules. The TRANSFOR institutions have been most fortunate in having people enthusiastic to tackle this job. The Canadian institutions welcome the evolving program accreditation principles being developed by the Canadian Forestry Accreditation Board (CFAB) under the "Inclusivity Project", as these and further adaptation of the European Credit Transfer System (ECTS) by the European institutions will make future exchanges easier to organize and operate.

\section{Student Internships}

TRANSFOR internships in Canada were designed to meet four objectives:

1. Inform students about forest management practices in the host region and provide experience in solving typical forestry problems dealt with by the host agency, which was generally a forest company or government ministry.

2. Allow students to present their project results to forest management experts.

3. Provide experience about Canadian culture and way of life.

4. Provide opportunities for students to improve their English language skills.
Internships with Canadian agencies generally lasted three to four months and were structured to include three basic components: 1) welcome and introduction; 2) project work in the forest sector (private industry or government); and 3) project result summary, presentation, and report.

TRANSFOR Interns working with J.D. Irving, Limited through UNB, for example, were assigned to mentors (either faculty members or graduate students from UNB with interest and expertise in the area of the project) and introduced to specifics of forestry in eastern Canada. They learned about the organization of forest management and professional secondary education in forestry in New Brunswick. The second component, which generally lasted 10 weeks, prompted students to learn about specific management and operating practices of their industrial host by job shadowing different supervisors during their daily job-related activities. They also worked on specific projects assigned and supervised by employees of J.D. Irving. University mentors supported the students in solving project related problems, as requested, through regular meetings scheduled to provide technical and professional advice. The experience was capped through delivery of a presentation and a technical report by the intern. Copies of the technical report were given to the host forest industry staff and to the universitybased mentors.

\section{Summer Field Courses}

Summer Field Courses have been the most innovative and, arguably, the most successful aspect of the TRANSFOR exchanges. In these, groups of 10-14 students, selected individually using criteria established at formal Project Meetings, were given the opportunity to participate in an international field course specifically designed to illustrate the main features of forestry on other continents. Funds from TRANSFOR (\$1900 per Canadian student and 1170 Euro per European student) covered airfares and approximately half of the daily on-the-ground costs (accommodation, food, travel and incidental expenses) for most students. Some partnering institutions were able to supplement TRANSFOR funds with additional support for their students, either as small grants or bursaries to cover the un-funded costs of travel during local legs of the field tour.

The purpose of the field courses was to introduce students to forestry activities and context on another continent. The student groups were accompanied by academic leaders and often by one or more students from the host institutions. In some years, students from within the host continent also accompanied the course. These arrangements encouraged much discussion of issues encountered, generally initiated on-site in the context of experiential learning opportunities, but often continued enthusiastically during travel legs and on into the evenings. Whenever possible, forest sector employees were drawn on to make on-site presentations and explain the broad context of various activities and their significance to the local forestry sector. Students who participated in these summer field courses were usually required to present a summary of their experiences at their home institution upon return to their regular programs.

The three-week course in Canada (Fig. 1) began with an orientation to forest management on publicly-owned land, the predominant forestry context, and ended with a wrap-up 

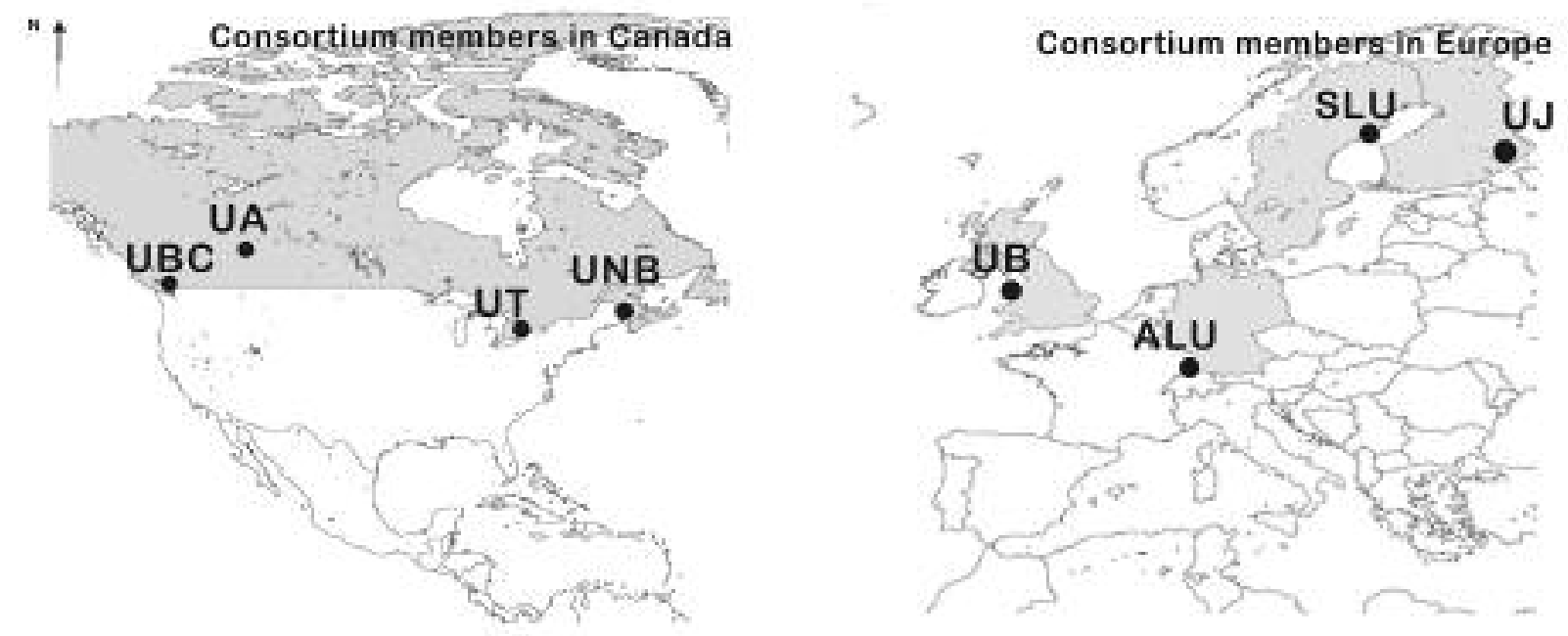

Fig. 1. Locations of TRANSFOR partner universities in Canada and Europe. Institutions: University of Alberta (UA); University of British Columbia (UBC); University of New Brunswick (UNB); University of Toronto (UT); Albert-Ludwigs University (ALU), Freiburg, Germany; University of Bangor (UB), UK; University of Joensuu (UJ), Finland; and Swedish University of Agricultural Sciences (SLU), Umeå, Sweden.

discussion that integrated the entire experience. Significant issues in the Canadian perspective of sustainable forest management were illustrated, including those involving First Nations, recreation and tourism, conservation of wildlife, fisheries and biodiversity. Specific issues related to forest management of major Canadian forest types were also covered, often in operational site visits and through presentations made by cooperating industrial or government personnel (Table 2). Canadian approaches to forest management planning, including those modeled on natural disturbance, and forestry education were also specifically addressed, as were specific problems of wildfire and pest management, and the role of foresters in managing urban forests that are increasingly threatened by invasive exotic agents.

Students participating in the European summer course (Fig. 1) were exposed to the main silvicultural systems used in Western Europe and the long history of their development, both in terms of stand conversion and patterns of land ownership. They witnessed first hand several harvesting systems and visited both wood processing facilities and the John Deere factory in Finland that produces logging equipment. They were exposed to European views of forest conservation, national parks, various options of sustainable forest management, including "close to nature" forestry, single tree selection and valuable wood production, and to forestry education and research in the European context. They saw how forestry activities have been integrated into highly anthropogenic landscapes that do not have the great sweep of unbroken natural forests that characterize much of Canada.

Topical balance of the tours was similar on both sides of the Atlantic, and the differences reflect variation between the Canadian and European forest sectors. The largest number of units included activities categorized as "management", which included applied forest ecology, silviculture, forest regeneration and specific management regimes applied to

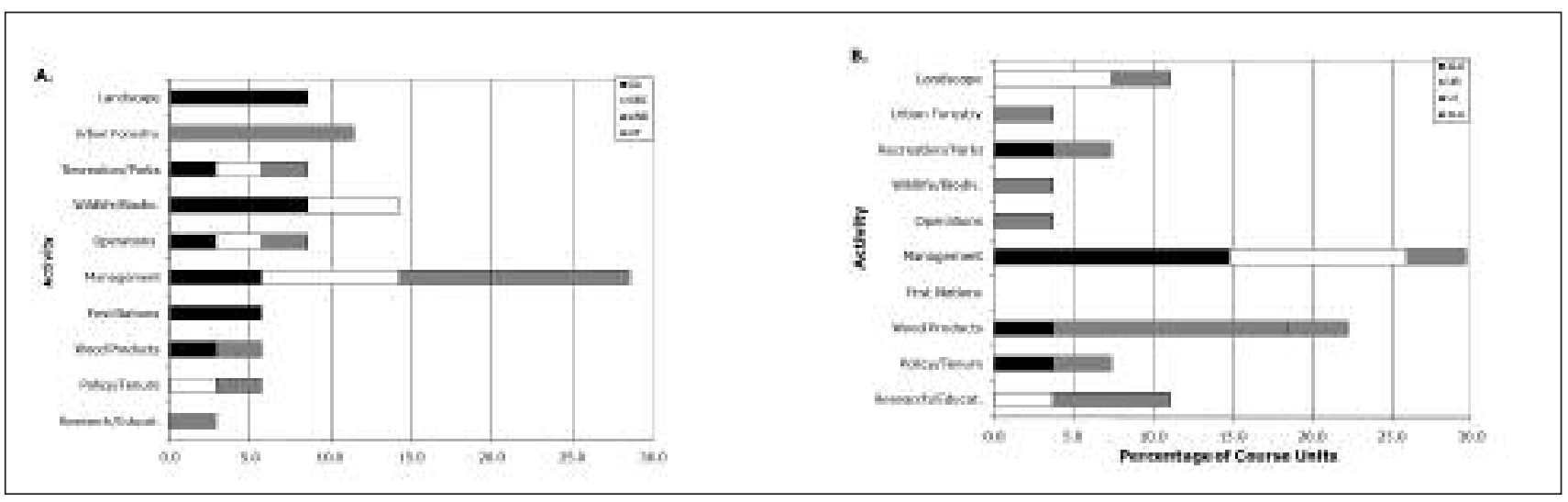

Fig. 2. Distribution of general activities in typical TRANSFOR Summer Field Courses as illustrated by the 2008 program. "Management" is a broad category including forest ecology, silviculture and forest management systems, as these were frequently blended in single sessions. (A) The Canadian Summer Field Course, as delivered by the four partner institutions. (B) The European Summer Field Course, as delivered by the four partner institutions. Institutional abbreviations as in Fig 1. 
Table 2. Selected "feature activities" in TRANSFOR Summer Courses as delivered by particular universities in association with partner organizations.

\begin{tabular}{|c|c|c|}
\hline University & Featured activity & Sponsors/co-operators \\
\hline \multicolumn{3}{|l|}{ Canada } \\
\hline \multirow[t]{2}{*}{ Alberta } & $\begin{array}{l}\text { Conservation of endangered species on } \\
\text { managed landscapes of publicly-owned } \\
\text { forest (grizzly bears) }\end{array}$ & Foothills Research Institute \\
\hline & $\begin{array}{l}\text { Forest fire suppression and use of } \\
\text { fire in park management }\end{array}$ & $\begin{array}{l}\text { Alberta Sustainable Resource Development, } \\
\text { Jasper National Park }\end{array}$ \\
\hline \multirow[t]{2}{*}{ British Columbia } & First Nations management of coastal rain forest & Squamish First Nation \\
\hline & $\begin{array}{l}\text { Forestry and commercial fisheries } \\
\text { (Pacific Salmon) }\end{array}$ & University of Northern British Columbia \\
\hline \multirow[t]{2}{*}{ New Brunswick } & $\begin{array}{l}\text { Intensive forest management on } \\
\text { company-owned land }\end{array}$ & J. D. Irving, Limited \\
\hline & $\begin{array}{l}\text { The Canadian and International } \\
\text { Model Forest Networks }\end{array}$ & Fundy Model Forest \\
\hline \multirow[t]{2}{*}{ Toronto } & $\begin{array}{l}\text { Urban Forest Management and } \\
\text { Urban-wildland interface }\end{array}$ & $\begin{array}{l}\text { City of Toronto, Eastern Ontario Model } \\
\text { Forest, Regional Municipality of York }\end{array}$ \\
\hline & Urban tree health and invasive species & Urban Forest Innovations Inc. \\
\hline \multicolumn{3}{|c|}{ European Community } \\
\hline \multirow[t]{2}{*}{ Bangor } & Plantation management on sandy soils & Newborough Forest \\
\hline & Forest management for multiple objectives & Gwydyr State Forest \\
\hline \multirow[t]{2}{*}{ Freiburg } & $\begin{array}{l}\text { Nature conservation and } \\
\text { landscape development }\end{array}$ & Naturschutzzentrum Südschwarzwald \\
\hline & Small-scale, rural forest enterprises & Forest District office Wolfach \\
\hline \multirow[t]{2}{*}{ Joensuu } & Forest science in support of modern forestry & $\begin{array}{l}\text { Finnish Forest Research Institute, } \\
\text { European Forestry Institute }\end{array}$ \\
\hline & $\begin{array}{l}\text { Forest-sector companies and } \\
\text { economic development }\end{array}$ & John Deere \\
\hline \multirow[t]{2}{*}{ Umeå } & Cut to length harvesting systems & Stora Enso Skog \\
\hline & Silviculture for biodiversity & Färna Ecopark, Sveaskog \\
\hline
\end{tabular}

woodland systems. In both Canada and Europe particular schools took the leads on specific topics judged to be centrally important to modern forest management on each continent (Table 2).

\section{Staff Study Visits}

A number of academic staff took advantage of the TRANSFOR funding to visit partnering institutions. These visits opened up significant opportunities for joint research projects and amplified the international understanding engendered through TRANSFOR, about both forestry and culture in other countries. These sorts of exchanges can assist the necessary development of cross-boundary social, cultural and technical understanding that has lagged behind the significant economic pressures to forge a global marketplace.

\section{TRANSFOR Project Meetings}

TRANSFOR program meetings fostered excellent interactions of academic staff members from most of the programs involved and contributed markedly to resolving curriculum issues that complicate exchanges, as mentioned above. Four face-to-face project meetings were held over a two- or threeday period annually in Freiburg (2005), Toronto (2006), Umeå (2007) and Edmonton (2008). The international understanding and enthusiasm that was generated during these meetings was inevitably passed down to students on both continents and contributed to the overall success of the program. In addition to review of the program in relation to project goals and generation of new ideas through discussion, these meetings also exposed the project leaders to significant forest sector issues on both continents through short field excursions. 


\section{Prospects}

The initial grant support for TRANSFOR ended in 2008, and the agencies that initiated TRANSFOR are unable to continue funding the program. Nonetheless, having now ironed out the exchange wrinkles, the TRANSFOR partners remain committed to, and very excited about continuing and expanding the program to involve other universities and, in particular, other regions. At present we are seeking new sponsors and marshalling internal resources to permit further exchanges in the future. There is no doubt that the program has met its goals and done a superior job of providing students from the partner institutions with an international perspective uncommon among forestry students. Furthermore, the program has conveyed a broader aspect of forestry to participants and clarified the central role of well trained foresters in promoting and developing successful approaches to meeting the manifold global challenges of sustainable forest management.

\section{Acknowledgements}

In addition to the co-operators listed in Table 2, the TRANSFOR partners gratefully acknowledge additional assistance from Elk Island National Park (Alberta), the Henfaes Research Centre (Wales), Koli National Park (Finland), Millar Western Forest Products Ltd., (Alberta) the Municipality of Huddinge (Sweden), the Ontario Ministry of Natural Resources, Padarn County Park (Wales), West Fraser Timber Company Ltd. (Alberta) and the Weyerhaeuser Company (Alberta). In addition to participating in the program, many co-operators subsidized the daily costs for the students by providing meals and/or accommodation. TRANSFOR would not have been possible without funding from the International Academic Mobility program of the European Union (EU), Human Resources and Skills Development Canada (HRSDC), and the Natural Resources Canada Canadian Model Forest Network (CMFN). 